PNL- -8519

DE93 007999

\title{
EELGRASS (Zostera marina L.) TRANSPLANT MONITORING IN GRAYS HARBOR, WASHINGTON, AFTER 29 MONTHS
}

R. M. Thom

January 1993

Prepared for the

U.S. Army Corps of Engineers - Seattle District Under a Related Services Agreement with the U.S. Department of Energy

Contract DE-ACO6-76RLO 1830

Pacific Northwest Laboratory

Richland, Washington 99352 


\section{SUMMARY}

In 1992, the U.S. Army Corps of Engineers-Seattle District, placed oyster shell on tidal flats to mitigate for Dungeness crab mortalities caused by dredging in Grays Harbor, Washington, in 1990. Shell placement damaged isolated patches of eelgrass. To help assess the potential for the recovery of eelgrass in plots that may have been significantly affected, eelgrass transplanting experiments were initiated in 1990. Eelgrass was transplanted into 16 ponded areas that were created by the uneven placement of the shell. Transplanting was carried out in spring 1990, and sampling of the survival of the transplants was conducted in August of 1990 and 1991. Battelle/Marine Sciences Laboratory was requested by the U.S. Army Corps of Engineers-Seattle District to analyze transplant success in selected plots after 29 months. Part of this analysis involved resampling transplanted eelgrass plots in August 1992.

Quantitative samples collected on August 11 and 12, 1992 indicated that transplanted eelgrass increased significantly in terms of shoot abundance over the 29 months since transplantation. The variation and rate of increase in shoot abundance among transplant plots can be partially explained by desiccation stress, with deeper ponds showing enhanced growth rate and plant size.

Four basic recommendations are made based upon the data:

1. The eelgrass plots should be resampled annually to provide much needed data on long-term survival and spread of transplanted eelgrass. (The plots should be remarked with raw stakes in 1993 to assure ease of relocation.)

2. The rate of increase in shoot abundance, shoot length, and perhaps plant migration appear to be strong indicators of the physical suitability of a site for eelgrass transplants. These parameters should be tested further using controlled experiments.

3. The hypotheses suggesting that a mixed eelgrass/shell habitat provides greater benefits to fishery resources as compared to shell alone should be investigated.

4. Eelgrass meadow construction through the use of stable ponds appears to be a viable technology but requires directed research on factors including optimal pond depth and size, maintenance of ponds, and optimal transplanting density to fully evaluate and refine the technique. 


\section{ACKNOWLEDGMENTS}

I sincerely thank Bert Brun from the U.S. Army Corps of Engineers-Seattle District for his continuing interest and valuable advice on eelgrass transplantation.

This research was supported by the U.S. Army Corps of Engineers under a Related Services Agreement with the U.S. Department of Energy (DOE) under Contract DE-AC06-76RLO 1830, Interagency Agreement TD3263. The Batte11e/Marine Sciences Laboratory is part of the Pacific Northwest Laboratory, which is operated for DOE by Battelle Memorial Institute. 
CONTENTS

SUMMARY .............................. . . i . . . . . .

ACKNOWLEDGMENTS . . . . . . . . . . . . . . . . . . . . . V

INTRODUCTION . . . . . . . . . . . . . . . . . . . . . 1

STUDY SITES ............................. . 3

TRANSPLANTING AND SAMPLING METHODS . . . . . . . . . . . . . . . . 5

RESULTS AND DISCUSSION ....................... 7

TRANSPLANTING RESULTS ...................... 7

TRANSPLANTED EELGRASS AS HABITAT . . . . . . . . . . . . . . 12

CONCLUSIONS . . . . . . . . . . . . . . . . . . . . 15

REFERENCES ............................ 17

vii 


\section{FIGURES}

1 Map of Grays Harbor Showing Shell Plot Locations . . . . . . . . . . 3

2 Temporal Changes in Shoot Abundance in Transplanted Plots . . . . . 8

3 Rate of Change of Shoot Abundance in Transplanted Plots Over

29 Months . . . . . . . . . . . . . . . . . . 9

4. Eelgrass Shoot Length Versus Pond Depth . . . . . . . . . . . . 10

5 Rate of Change of Shoot Abundance in Transplanted Plots Over

29 Months Versus Pond Depth . . . . . . . . . . . . . . . . 11

6 Diagram of a Mixed Eelgrass/Shell Habitat ............. . 13 


\section{INTRODUCTION}

In 1992, the U.S. Army Corps of Engineers-Seattle District placed oyster shell on tidal flats to mitigate for Dungeness crab (Cancer magister) mortalities that were caused by dredging in Grays Harbor, Washington, in 1990. Experimental shell test plots of 0.4 ha (1 acre) were established in April 1990, to evaluate the proposed mitigation method (Armstrong et a1. 1991). Because some of the plots contained eelgrars, there was a general concern regarding the impact of shell placement on natural stands of eelgrass. Studies conducted by Thom and Hallum (1991) showed that isolated patches of eelgrass probably were damaged.

To help assess the potential for eelgrass recovery in plots that may have been significantly affected, eelgrass transplanting experiments were initiated in 1990. Eelgrass was transplanted into 16 areas that contained ponded water during low tides. These ponded areas were created by the uneven placement of the she11. Observations in Grays Harbor indicated that eelgrass occurred most frequently in ponds on flats, as opposed to areas that were dry during low tide, and in shallow subtidal areas that fringed the flats. Thom and Hallum (1991) reasoned that plants $p l a c e d$ in ponds would have a higher probability of surviving compared with plants placed in areas that were more prone to desiccation. Transplanting was carried out in spring 1990, and sampling of the survival of the transplants was conducted in August 1990. In August of 1991, eelgrass shoots were counted in two of the ponds located at the Campbell Slough shell plots. The samplings indicated general increases in shoot abundances from those originally transplanted.

The U.S. Army Corps of Engineers-Seattle District requested Battelle/Marine Sciences Laboratory (MSL) to resample as many of the transplanted areas as possible to provide information on transplant success after 29 months. Six transplant areas were resampled in August 1992; two areas at the Campbell Slough plot and four areas at the South Channel plot. A summary is presented of the potential for using eelgrass transplants in conjunction with shell placement as a method for enhancing the habitat diversity and potential benefit to fisheries resources, including Dungeness crab. This limited transplant study represents one of few attempts in the Pacific Northwest to document eelgrass transplanting over a relatively long period of time (Thom 1990a). The previous success of most eelgrass transplanting efforts in this region has been poor or poorly documented. 


\section{STUDY SITES}

The experimental shell plots were located in Campbell Slough, on the northern and southern sides of the Grass Creek Channel and in South Channel (Figure 1). The sites selected were chosen to maximize shell plot stability, to cover minimal stands of eelgrass, and to maximize the probability of crab settlement. Rectangular 0.4-ha $(40 \times 100 \mathrm{~m})$ shell and control plots (adjacent to the shel1 plots) were established at each site in April 1990. Biologists, including resource agency personnel, University of Washington researchers, and U.S. Army Corps of Engineers biologists selected the position of the test plots, which appeared qualitatively to contain less eelgrass than the control plot. The plots were marked with wooden stakes and floats to facilitate shell placement and relocation for future crab and eelgrass sampling.

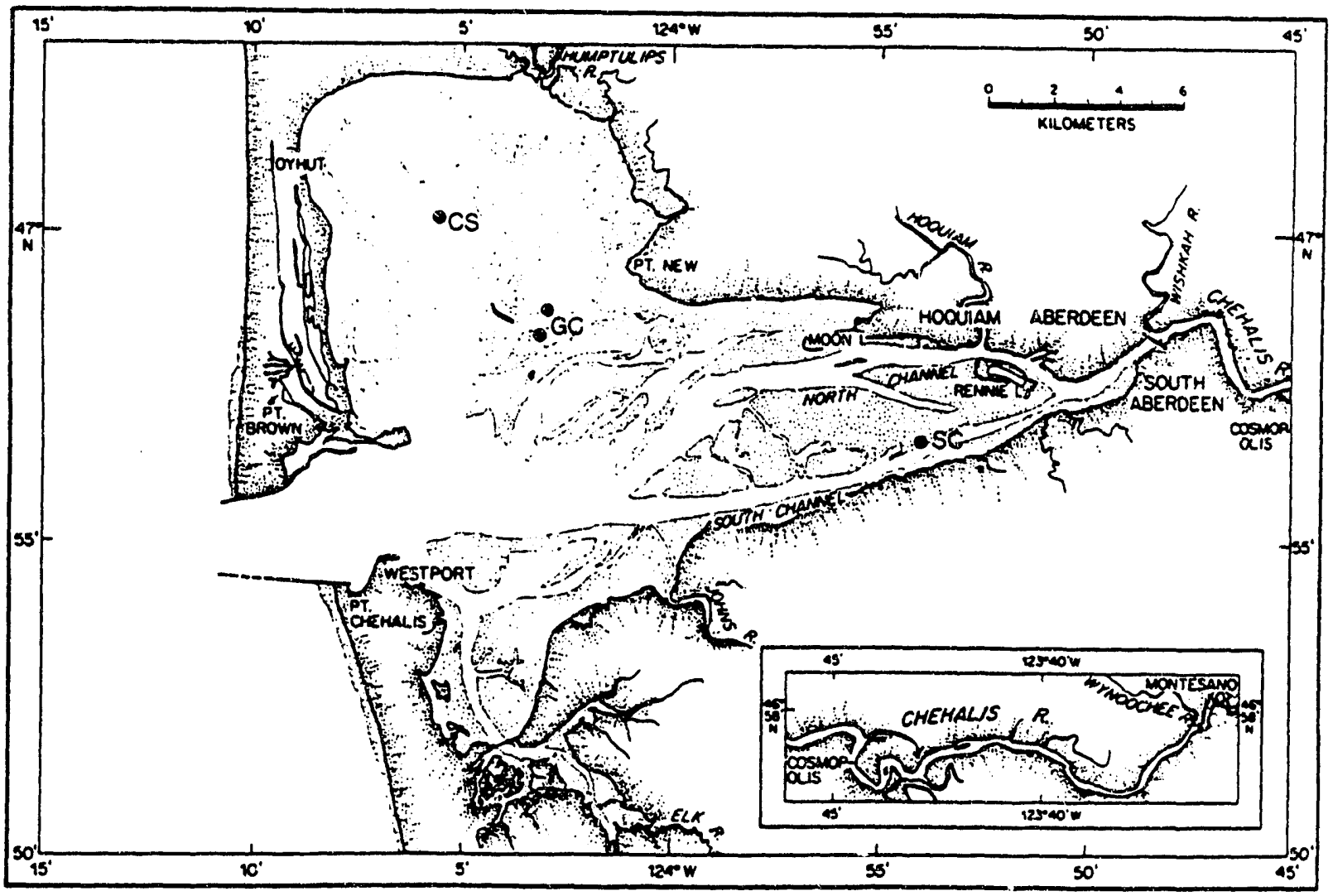

FIGURE 1. Map of Grays Harbor Showing Shell Plot Locations (CS = Campbel1 Slough, GC = Grass (reek, SC = South Channe1) 


\section{TRANSPLANTING AND SAMPLING METHODS}

In April and May 1990, Thom and Hallum (1991) transplanted eelgrass shoots, with attached roots and rhizomes, into ponds (approx. 1-6 cm deep) that were created by placing shell in the plots. Most of the plantings were done by bundling ten eelgrass shoots together using a plastic-covered metal twist-tie, around a metal wire. The wire, which protruded below the rhizomes approximately 10-15 cm, served as an anchor for the shoot bundles. Material for the transplants was gathered immediately adjacent to the plot to minimize both handiing time and the time the below-ground parts were exposed to air. A total of 16 ponds (eelgrass transplant plots) in the 4 shell test plots received $50-150$ shoots each. Individual shoots, or shoot bundles, were planted with spacing of 10-20 cm. Counts of the number of shoots (i.e., aboveground portions) per pond were made in August 1990. Two ponds within the Campbell Slough plot were counted in August 1991. On August 11 and 12, 1992, eelgrass shoots were counted in the two Campbell slough plots and in the four ponds located in the shell plot at South Channel. In addition, lengths of 10-15 randomly selected shoots were measured within each pond; and in four reference ponds adjacent to the South Channel shell plot. Finally, pond depth was measured at 6-7 locations within the areas where the shoots were counted and measured. 


\section{RESULTS AND DISCUSSION}

\section{IRANSPLANTING RESULTS}

The areas that were transplanted were relatively easy to relocate by referring to the wooden stakes placed there in 1990. The Campbell Slough shell plot had changed considerably since 1990 due to sediment movement and shell burial. The transplanted areas may become increasingly difficult to relocate in future years because of rapid changes in sediment distribution and loss of marker stakes.

Shoot abundance increased an average of 3.1 times (SD $=2.5)$. This means that, on average, 100 shoots increased to 310 shoots between spring 1990 and August 1992 (Figure 2). The 95\% confidence limits around this average ranged from a decrease of 50 shoots to an increase of 570 shoots. The greatest increase occurred at both the Campbell slough ponds. Two of the six transplanted ponds showed only a slight $(<10 \%)$ increase in shoot abundance. One pond (South Channel 4) declined by August 1990, but increased to near the original transplant abundance by August 1992. The original transplants were not evident as discrete bundles, and the center of most transplanted areas had shifted slightly. This could be due to natural migration of the shoots as a result of rhizome growth and/or dieback of plants in marginal areas of the ponds.

The rate of change in shoot abundance averaged 4.7 shoots/month over the 29 months since transplanting (Figure 3), with a range of <1 to almost 12 shoots/month. Twelve shoots/month may represent near-optimal rates of increase, which reflect optimal physical conditions for transplanting in the areas that were studied.

The measurements of shoot length generally showed that transplants had similar shoot lengths as compared with natural stands (Figure 4). In addition, the relatively strong regression relationship indicated that pond depth was positively correlated with shoot length. Ponding probabiy reduces desiccation stress for plants on the flats. The rate of change in shoot abundance for the planted material also showed a positive relationship with pond depth (Figure 5). However, to verify this relationship, further experimental studies on more sites would be required. 


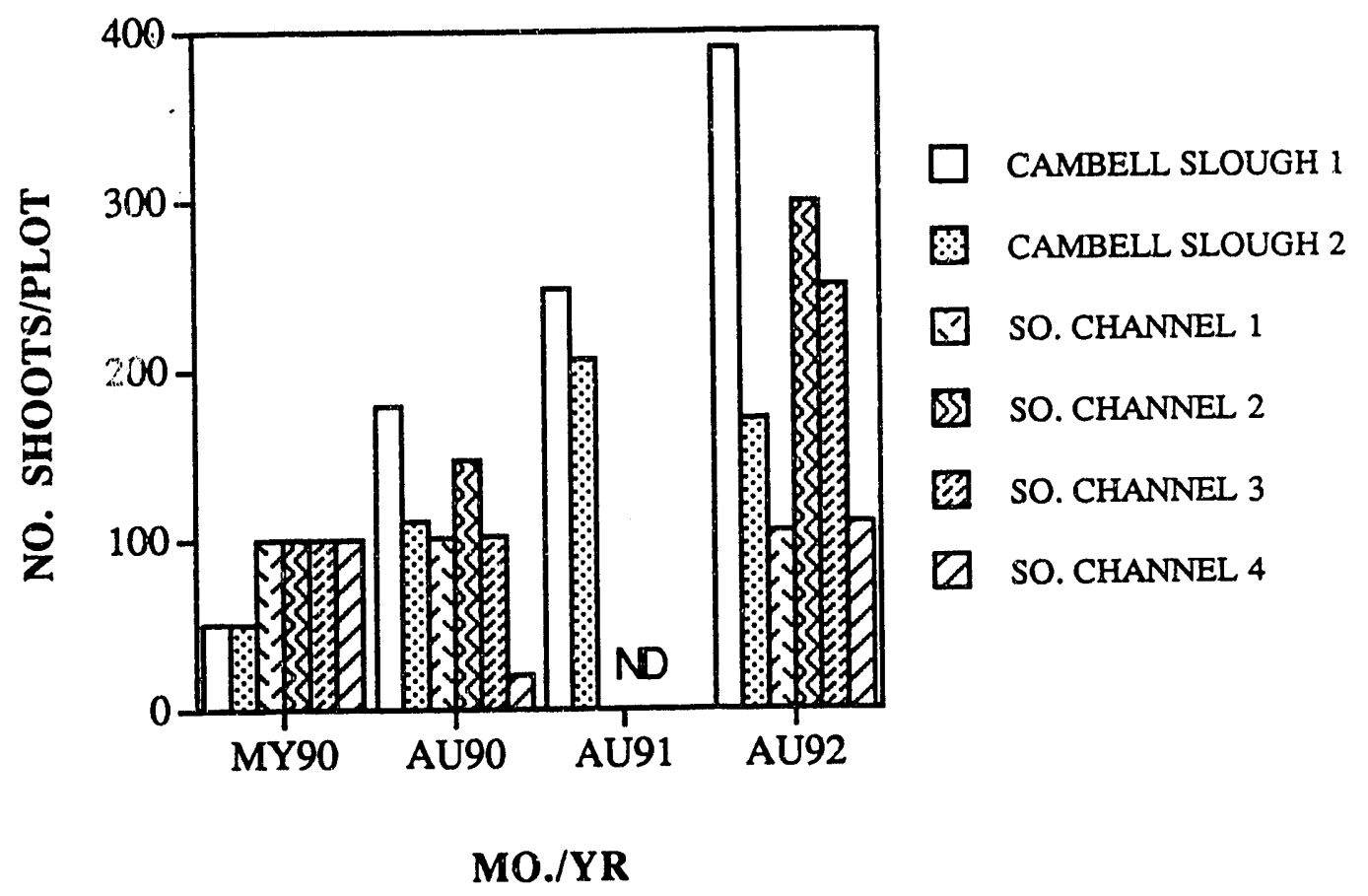

FIGURE 2. Temporal Changes in Shoot Abundance in Transplanted Plots (ND = No Data) 


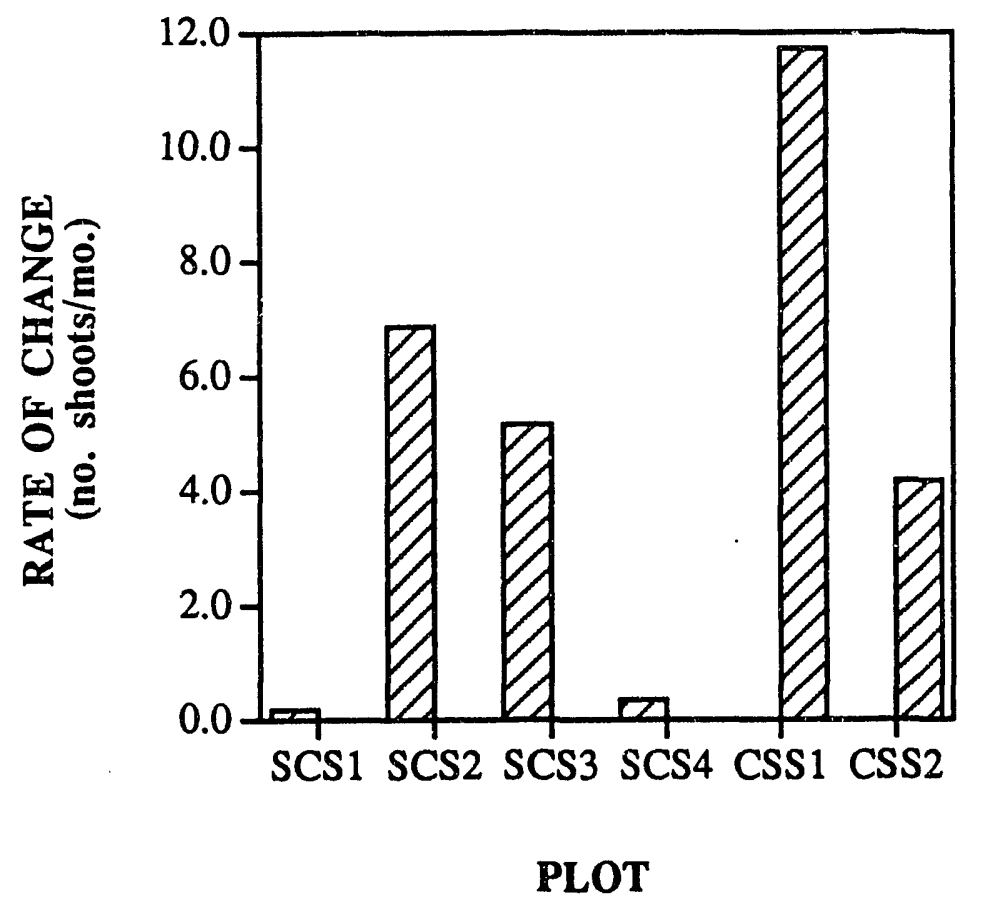

FIGURE 3. Rate of Change of Shoot Abundance in Transplanted Plots Over 29 Months 


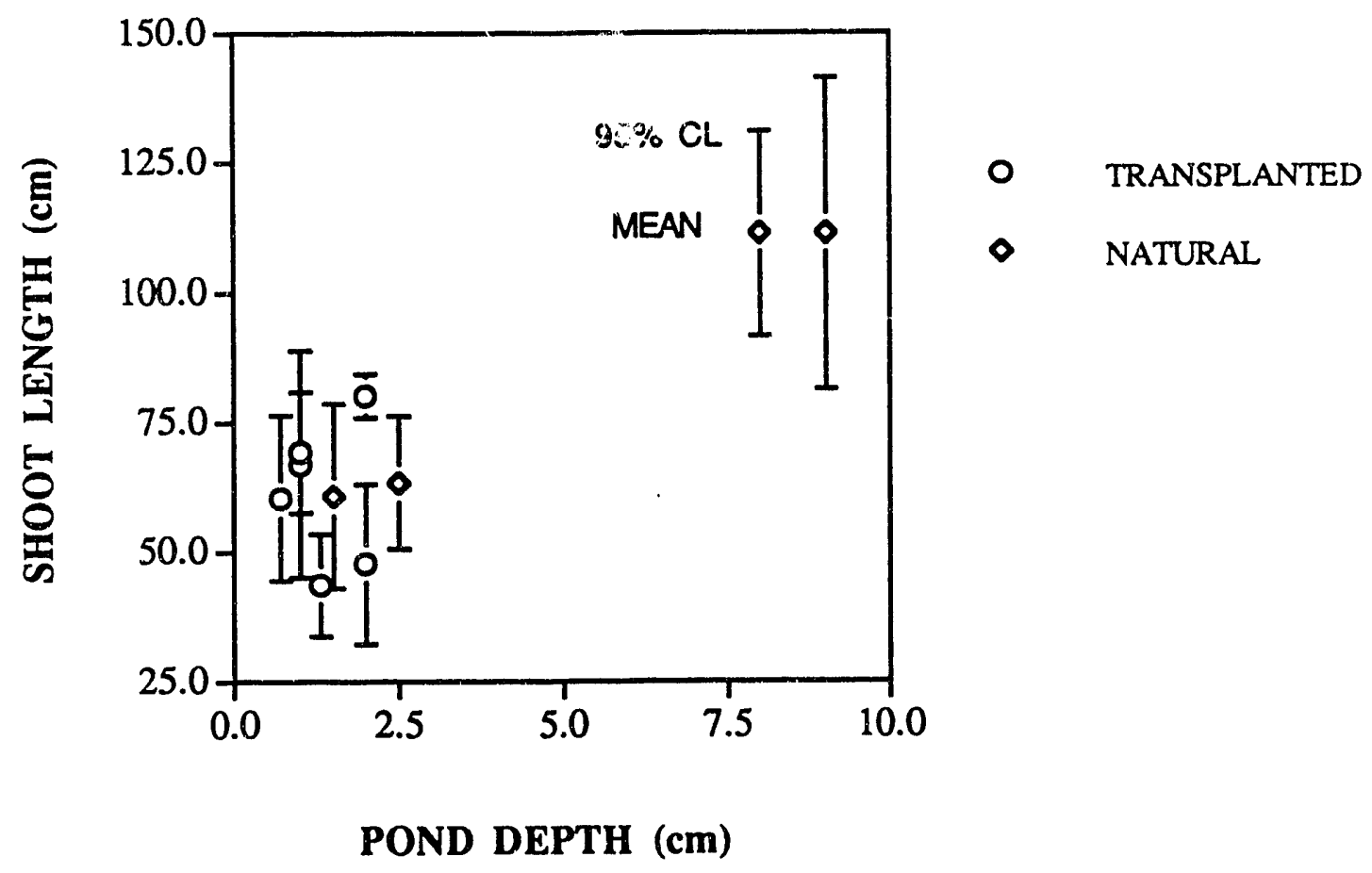

FIGURE 4. Eelgrass Shoot Length Versus Pond Depth 


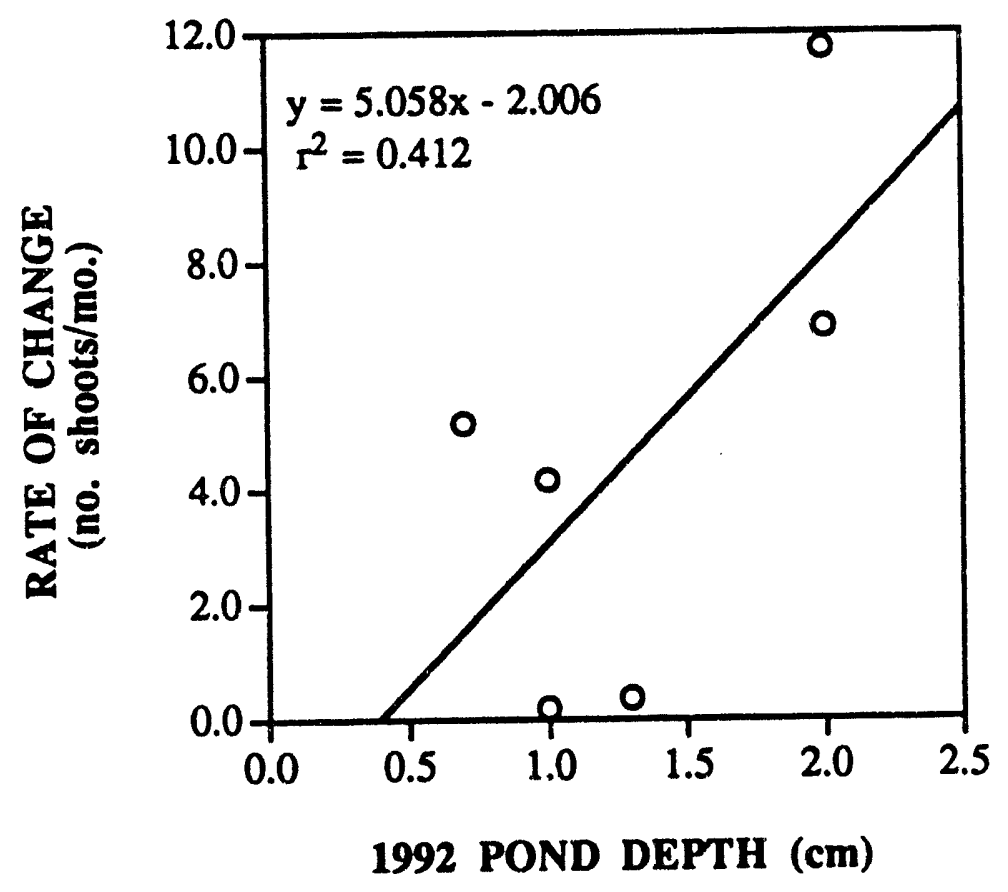

FIGURE 5. Rate of Change of Shoot Abundance in Transplanted Plots Over 29 Months Versus Pond Depth 
The long-term iate of the transplants may depend on the persistence of ponded water. Mean pond depth for the six ponds decreased from $2.8 \mathrm{~cm}(S D=1.9)$ in 1990 to $1.3 \mathrm{~cm}(S D=0.6)$ in 1992 , which indicates the ponds are filling. Eelgrass meadows trap sediments and organic matter under natural conditions and tend to raise the sediment surface. The rate of accretion is highly variable and depends on a variety of factors, including sediment input, wind driven waves, and surrounding topography. Scouring could occur adjacent to the areas where the eelgrass is presently growing. Based on the observations in 1992, eelgrass can spread, via rhizomes, to occupy adjacent ponds created by scouring that are most suitab? e for their growth. Eelgrass is known to show large annual vations in distribucion on the flats in Grays Harbor, and this may be in response to shifting topography. It is too early to predict the long-term fate of the transplants in Grays Harbor.

\section{TRANSPLANTED EELGRASS AS HABIYHT}

The use of eelgrass by Dungeness crab, juvenile salmon, and other fisheries resources in the Pacific Northwest is well-documented. Studies by Armstrong et al. (1981, 1991), Dinnell et al. (1986), and Gunderson et al. (1990) illustrate the use by newly settled crabs of estuarine habitats, in particular eelgrass meadows and shell piles. Eelgrass offers protection from predation, as well as increased benthic food resources and perhaps decreased desiccation stress.

A simple diagram of a system that includes shell piles interspersed with eelgrass patches is shown in Figure 6 . This mixed system essentially increases habitat diversity in terms of substrata composition and vertical height. Landscape ecology theory shows that greater habitat diversity results in greater species diversity. Fish are generally attracted to vertical structures in water and wouid be expected to congregate in, and around, eelgrass patches. Juvenile salmon are known to prey heavily on harpacticoid copepods and other small crustacea associated with the epiphytes attached to eelgrass. Although still to be evaluated, the benefits gained on juvenile salmon, such as refuge from predation and production of food resources, from shell plots with significant eelgrass area may be greater than from plots with shell alone. Densities of young crabs are lower in eelgrass than in shell plots (Armstrong et al. 1991). However, detritus production by eelgrass and transport of detritus to the shell 


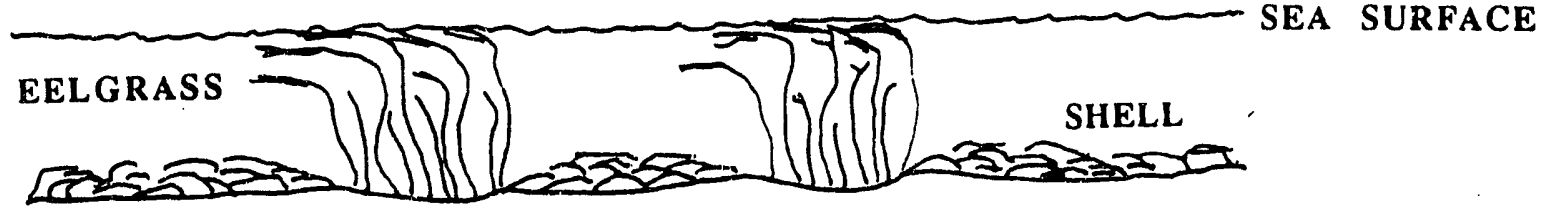

FIGURE 6. Diagram of a Mixed Eelgrass/Shell Habitat 
may enhance secondary productivity in the adjacent shell. Observations made in 1990 showed that diatoms and seaweed did attach to shel1. However, these taxa are generally short-lived and are not persistent components of the habitat. In contrast, eelgrass persists throughout the year and forms habitat for a variety of different species, depending on the season. Furthermore, eelgrass production dynamics differ from those of the ephemeral algae associated with shell. In general, eelgrass production occurs throughout spring and summer, in contrast to ephemeral algae, which have an early summer bloom and dieback. This longer growth period of eelgrass results in a longer period of detritus production in the habitat. In addition, leakage of organic material from the leaves of the plant can provide significant quantities of organic matter to the planktonic system (Thom 1990b). Finally, eelgrass meadows have sediments that are high in organic content from the trapping of organic matter and the growth of roots and rhizomes. These conditions enhance the production of infauna, which may be eaten by fish and crabs that use the habitats. A criticism of shell-only plots is that they do not benefit animals other than crab. Studies that critically evaluate a mixed she11/eelgrass system are needed to provide evidence for methods that enhance mitigation or impacts to a wide range of target fisheries species. 


\section{CONCLUSIONS}

Transplanted eelgrass increased significantly in terms of shoot abundance over the 29 months since it was transplanted. Considerable variation in shoot abundance and rate of increase among the transplant plots can be partially explained by desiccation stress. In general, deeper ponds showed enhanced growth rate and plant size. The eelgrass distribution did change since it was transplanted, which may be a result of rhizome spread. Eelgrass that was incorporated into plots containing shell may provide several ecological benefits to fish and crabs, and may increase overall habitat produr,tion.

There are four basic recommendations based on the information gathered to date:

1. The eelgrass plots should be resampled annually to provide much needed data on the long-term survival and spread of transplanted eelgrass. (The plots should be remarked with new stakes in 1993 to assure ease of relocation.)

2. The rates of increase in shoot abundance, shoot length, and perhaps $p l$ ant migration appear to br trong indicators of the physical suitability of a site for eelgrass tr... using controlled experiments.

3. The hypothesis suggesting that a mixed eelgrass/shell habitat provides greater benefits to fishery resources, as compared to shell alone, should be investigated.

4. Eelgrass meadow construction through the use of stable ponds appears to be a viable technology, but requires directed research on optimal pond depth and size, pond maintenance, and optimal transplanting density to fully evaluate and refine the technique. 


\section{REFERENCES}

Armstrong, D.A., B.G. Stevens, and J.C. Hoeman. 1981. Distribution and Abundance of Dungeness Crab and Crangon Shrimp and Dredging-Related Mortality of Invertebrates and Fish in Grays Harbor, Washington. Grays Harbor and Chehal is River Improvements to Navigation Environmental Studies. U.S. Army Corps of Engineers, Seattle District. Seattle, Washington.

Armstrong, D.A., K.A. McGraw, P.A. Dinnel, and 0. Iribarne. 1991. Construction Dredging Impacts on Dungeness Crab, Cancer magister, in Grays Harbor, Washington and Mitigation of Losses by Development of Intertidal Shell Habitat. Fisheries Research Institute, University of Washington, Seattle, Washington.

Dinnell, P.A., R.0. McMillan, D.A. Armstrong, T.C. Wainwright, A.J. Whiley, R. Burge and R. Bumgarner. 1986. Padilla Bay Dungeness crab, Cancer magister, habitat study. Report to NOAA/OCRM/MEMD by Univ. Wash., Fisheries Research Institute. 78 pp. Seattle, Washington. Padilla Bay National Estuarine Research Reserve Reprint Series No. 3, 1990.

Gunderson, D.R., D.A. Armstrong, Y.-B. Shi and R.A. McConnaughey. 1990. "Patterns of Estuarine Use by Juvenile English Sole (Parophrys vetulus) and Dungeness Crab (Cancer magister)". Estuaries. 13:59-71.

Thom, R.M. 1990a. "A Review of Eelgrass Transplanting Projects in the Pacific Northwest". The Northwest Environmental J. 6:121-137.

Thom, R.M. 1990b. "Spatial and Temporal Patterns in Plant Standing Stock and Primary Production in a Temperate Seagrass System". Botanica Marina. 33:497-510.

Thom, R.M. and L. Hallum. 1991. Eelgrass (Zostera marina L.) Studies Associated with Crab Mitigation in Grays Harbor Estuary, 1990. Chapter III in Armstrong, D.A., K.A. McGraw, P.A. Dinnel, and 0. Iribarne. Construction Dredging Impacts on Dungeness Crab, Cancer magister, in Grays Harbor, Washington and Mitigation of Losses by Development of Intertidal Shell Habitat. Fisheries Research Institute, University of Washington, Seattle, Washington. 


\section{DISTRIBUTION}

No. of

Copies

\section{OFFSITE}

2 DOE/Office of Scientific and Technical

Information

Ms. Lauran Cole

U.S. Army Corps of Engineers, Seattle District

P.0. Box C-3755

Seattle, Washington 98124-2255

\section{ONSITE}

DOE Richland Field Office

D. R. Segna

14 Pacific Northwest Laboratory

R. M. Thom (3)

R. M. Ecker

SEQUI

D. K. Shreffler

R. E. Schrempf

J. A. Trelstad

Publishing Coordination

Technical Report Files (5)

\section{SEQUI}

SEQUI

K6-86

SEQUI

Routing
M. J. Graham
K6-78
C. J. Hostetler
$K 6-81$
P. M. Irving
K6-98
R. L. Skaggs
K6-77
C. S. Sloane
K6-04
P. C. Hays (1ast)
K6-86 

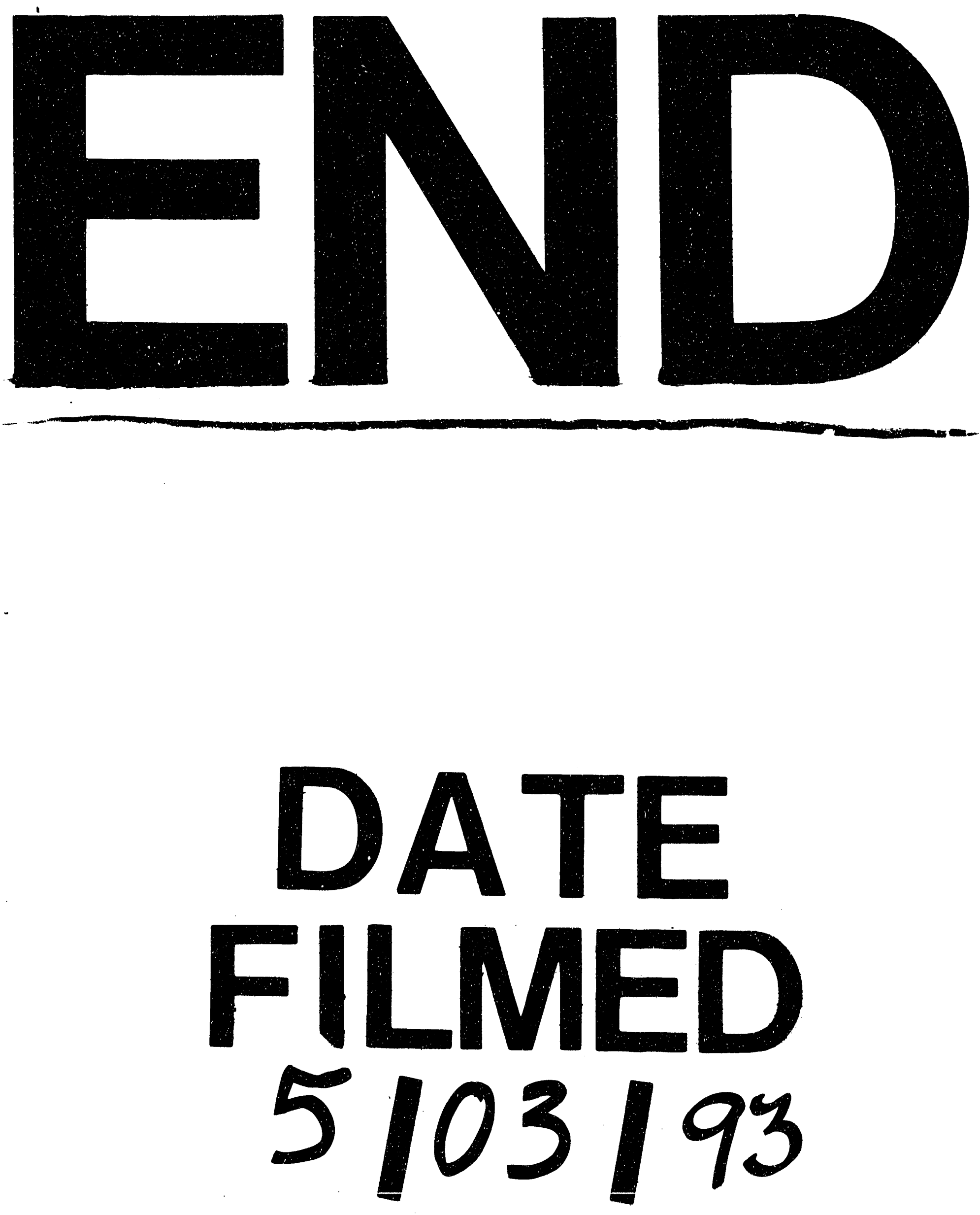
1 